\title{
Perestroika and New Thinking: A Retrospective
}

\author{
Mikhail S. Gorbachev
}

\author{
Mikhail S. Gorbachev \\ The last leader of the Soviet Union, he was General Secretary of the Communist Party from \\ 1985 until 1991, and President of the USSR in 1990-1991. \\ This is an abridged version of English-language article by Mikhail S. Gorbachev published \\ in Russia in Global Affairs (https://eng.globalaffairs.ru/articles/perestroika-and-new- \\ thinking/).
}

DOI: $10.31278 / 1810-6374-2021-19-4-10-21$

Perestroika inherited a difficult situation in terms of interethnic and federal relations. I have to admit that when we started perestroika, my colleagues and I did not see the full extent of that problem.

It is obvious now that preserving and renewing the country that represented "a world of many worlds" - a conglomerate of nations as different as, say, Estonia and Turkmenistan-was, objectively, a daunting challenge. In the years of perestroika, everything that had been accumulating in this sphere for decades and centuries erupted to the surface. I do not think that anyone was prepared for that.

Historically, the Soviet Union was the heir to the Russian Empire. Was the empire really a "prison of nations," as it was once called? If so, we must regard the Russian people as its first inmate. During the years of the Stalin regime, it suffered at least as much as the other peoples of the Soviet Union did.

All of this notwithstanding, it is also true that these peoples coexisted and created many great things together and that there was a chance to preserve the best of their common experience in new forms.

Why was that possibility not realized? 
The president of Russia, Vladimir Putin, has on a number of occasions laid the major share of the blame for the breakup of the Soviet Union on Lenin's concept of federation, which included the principle of sovereignty of the Soviet republics and the possibility of their selfdetermination, up to secession. But is that the real reason? We know that many empires and states have broken up even though their constitutions did not allow for such a possibility.

I believe the reasons lie elsewhere.

Under Stalin, the multinational state was cemented into a supercentralized single entity, with the center deciding and controlling everything. On top of that, Stalin and his associates carved territories and borders arbitrarily, as if they were trying to make sure that no one could even think of separation. The nationalities problems were buried deeply, but they did not disappear. Behind the façade of "peoples flourishing and drawing closer together," there were acute problems that no one sought to address. Stalin regarded any national claims and interethnic disputes as inherently anti-Soviet and suppressed them without further ado.

With democratization and greater freedom, it was inevitable that this would come to the surface. We have to recognize that we initially underestimated the scale and severity of the problem, but once it emerged, we could not resort to the old methods of suppression and prohibition. We believed that we must take a different path and seek thoughtful and balanced approaches using methods of persuasion.

In early 1988, when the Nagorno-Karabakh problem had come to a head, we understood that its roots were deep and that it had no quick solution-which, by the way, is still the case. Although some people tried to persuade me that re-carving the borders of Armenia and Azerbaijan would solve the problem, the country's leadership unanimously agreed that this was unacceptable. I believed that it was up to the Armenians and Azerbaijanis to reach an agreement; the central government was there to help them normalize the situation and, in particular, solve the economic problems. I remain convinced that this was the correct course.

However, neither the Party bodies nor the intelligentsia of the two republics were able to make progress towards an accord or at least a 
dialogue, leaving the way open to extremists. The situation escalated rapidly. In late February 1988, there was bloodshed in the Azerbaijani city of Sumgait. Troops had to be sent in to stop the massacre.

During that period, in 1987 and 1988, I sought to develop a consistently democratic approach to interethnic disputes. Essentially, it was based on the assumption that nationalities problems could only be properly resolved within the overall context of political and economic reforms. It must be said that initially, the national movements in the Baltic republics, Moldova, Georgia, and Ukraine declared their support for perestroika. In 1987, practically no one was proposing to leave the Soviet Union.

It soon became clear, however, that the national movements were being taken over by separatist elements, while the Party leaders in the republics were losing their bearings and were unable to act in a democratic environment. This is what happened in Georgia when people took to the streets of Tbilisi in April 1989. Members of the Central Committee of the Communist Party of Georgia should have reached out to the people, but instead they preferred to wait it out in a bunker. This ended disastrously: force was used "to clear the square" of the protesters, leaving 19 people dead and dozens injured.

This is a painful memory. But I can say with a clear conscience that the decision to break up the protest in Tbilisi was taken behind my back and against my will. Then and afterwards, I took a principled position: even the most difficult issues must be resolved by political means, without the use of force, without bloodshed.

\section{STRUGGLING TO KEEP THE UNION}

My critics assert that in paying primary attention to international problems and seeking to solve them on the basis of New Thinking, I underestimated the severity of the Soviet Union's domestic problems and missed opportunities to address them. In fact, during those years, particularly in 1991, I dedicated the lion's share of my time, efforts and strength to domestic politics, primarily to efforts to preserve our Union as a single entity.

What led us to the crisis in 1991? Why did events take such a sharp turn? The reasons were both objective, caused by the legacy of the 
Soviet state's decades-long existence, and subjective, related to mistakes and failings during the years of perestroika.

The problems of interethnic relations, federal-regional relations, and economic problems tightened into a single knot that could only be untied by resolutely modernizing those relations and implementing radical economic reform. We were slow to fully realize this, but when we did, we acted.

On the eve of 1991, I addressed the citizens of the country, saying: "The coming year will be special. At stake is the future of our multiethnic state. The peoples of this country have been living together for centuries. Perhaps we now realize more than ever before that we must not live behind fences that would separate us. To find a way out of the crisis and firmly follow the road of renewal, we must work together."

I was convinced that the problem of preserving and reforming the Union could be addressed politically, without the use of force and bloodshed. But as early as the first half of January, a storm broke out. There was bloodshed in Lithuania.

The leadership of Lithuania, having come to power as a result of elections, opted for exacerbating relations with the Union's central government and achieving independence at any cost. Nevertheless, I was looking for a compromise and was ready to negotiate. On January 12, I stated that the crisis would be resolved by constitutional means. But on the night of January 12 to 13 , the TV tower and a radio station in Vilnius were taken over with the help of Soviet troops and several people were killed.

As president of the Soviet Union, I did not order and could not have ordered such actions. They were a provocation against me as president, as would later-particularly after the attempted coup in August 1991become abundantly clear. There are documents to prove it.

After the bloodshed of January 13, any efforts to prevent the withdrawal of Lithuania and the other Baltic republics from the Soviet Union were doomed. But the struggle for the Union continued.

I was confident that issues relating to the fate of the Union state and of our nation must not be addressed without the participation of the people. I was convinced that at a referendum, the vast majority would support the preservation of the Union and its transformation into an effective federation. 
On March 17, 1991, at the referendum I initiated, 76 percent of the country's voters and 71.34 percent in Russia said yes to the Union. The results were equally impressive in Ukraine and Byelorussia. President of Russia Boris Yeltsin, who had assumed the role of radical opposition leader, and his entourage had to reckon with that outcome. This is what made it possible to convene regular meetings between the Soviet president and the leaders of nine republics, including Russia, Ukraine, Byelorussia, and Kazakhstan, at Novo-Ogarevo. Those meetings helped to ease tensions and speed up the preparation of the draft Union Treaty.

Together with my like-minded supporters, I simultaneously had to fight the attempts of separatists and "radical democrats" to dismember the Union and the actions of those who wanted to wind down the democratic process and throw our country back into the past.

At the April plenum of the Party's Central Committee, the latter went so far as to demand a change of leadership. The upper echelons of the Party sought support from the rank and file. Groups were emerging that called for "fighting revisionism" and "restoring the dictatorship of the proletariat."

Dozens, even hundreds, of letters from Party committees reached my desk, their ultimatums demanding "immediate measures to save the socialist system," up to declaring a state of emergency. On April 22, during the debate in the Supreme Soviet on the Cabinet of Ministers' report on how to end the economic crisis, some deputies-prompted by Prime Minister Valentin Pavlov and with Chairman of the Supreme Soviet Anatoly Lukyanov sympathetically looking on-began to speculate about declaring an emergency across the country or in crucial sectors of the economy. I had to intervene to counter the hard-liners and bring the parliament back to normal work.

Some members of the country's leadership, even some of my close associates, were two-faced people who professed their commitment to democracy while at the same time being ready to betray it and me. Of course, every one of them had the right to their own opinion, but they had every opportunity to state it directly, to argue and fight for it in open political debate. Instead, they chose to collude behind the scenes, ultimately attempting a coup détat. Promoting some of them, including 
nominating Gennady Yanaev for the post of vice-president, was a grave mistake, but at the time this was not so obvious.

My own choice, however, remained firm: stay the course of democracy, reject extreme measures proposed by hard-liners, and seek unity among all healthy elements of our society for the sake of reforms. So when in April representatives of the Party nomenklatura went all out and demanded that I either declare a state of emergency or resign as general secretary, I said:

"Enough demagoguery, I am resigning."

When asked to reconsider my decision, I refused and went back to my office. An hour and a half later, an overwhelming majority of the Central Committee, with just 13 members voting against and 14 abstaining, accepted the Politburo's proposal to delete my statement of resignation from the agenda.

Looking back, I think that agreeing to stay on as general secretary was a mistake. As subsequent events would make clear, the Party remained a conservative force, incapable of transforming itself and unwilling to participate in reforms.

Some high-ranking officials, too, failed the test of democracy. At a Supreme Soviet session in June 1991, Prime Minister Pavlov, supported by top security officials, demanded that the parliament grant the Cabinet of Ministers emergency powers. I was not present at the meeting because I was at Novo-Ogarevo conferring with the leaders of the republics on the final draft of the Union Treaty.

Once again, I had to take a stand to rebuff the proponents of emergency. It was now clear that in the new leadership to be formed after the signing of the Union Treaty, there would be no place for Pavlov, KGB Chairman Vladimir Kryuchkov, Defense Minister Dmitry Yazov, and Chairman of the Supreme Soviet Lukyanov.

This was the context in which the Union Treaty was being drafted, with contentious debate going on over its key provisions. Following complicated political maneuvering, arguments and clashes of opinion, by the end of July we were coming close to finding reasonable solutions to the problems that impeded perestroika. That created the prerequisites for overcoming the crisis. 
The completion of the work on the Union Treaty on July 23 was, of course, of decisive importance. We had reached agreement on issues related to the rights and powers of the republics and the central authorities, a common monetary policy, and taxes. Also in July, we began to implement an anti-crisis economic policy. It was the result of hard work, but in the end, we agreed on a version that received support from the republics, and even the Baltic leaders were ready to act in accordance with that program.

It all came together in July 1991, and it was the outcome of longstanding and arduous efforts on the road upon which we had first embarked in 1985. The real prerequisites were now in place for pulling the country out of the crisis and making a major breakthrough in implementing democratic reform.

\section{FAILING TO MEET THE NEEDS OF THE TIMES}

During those months, our activity in the international arena was subordinated to one goal: consolidate the transition from confrontation to cooperation and ultimately to partnership in relations with the world's major powers and move towards real integration of our country into the global economy. This was the key objective that underlay the central events of the 1991 foreign policy agenda: my participation in the meeting of the Group of Seven leading industrialized countries in London and U.S. President George Bush's visit to the USSR.

By the time I met with the G7 leaders, we were ready for serious discussion. Perestroika had liberated us from the dogmas that had stood in the way of recognizing that a modern, efficient economy cannot exist without private property, economic freedom, and market economics. In the years before glasnost, when fear still prevailed, our politicians and economists did not dare even speak those words. But by 1990, we could say that there was consensus in our society and among experts on the need to move towards a market economy.

During my meetings with Western representatives in the fall of 1990, I always emphasized that overcoming our economic crisis and reforming the economy was our responsibility, something that no one could do for us. We understood that. But the West, too, had a stake in 
our success. A healthy economy in our vast country was by all means in the West's interests. Therefore, at the most difficult, make-or-break moment in our reforms, we had every reason to hope that our partners would take steps in our direction.

Yet our Western interlocutors suggested, directly or indirectly, that reforms in the USSR were still going too slowly and that our economy was "insufficiently market-oriented," making it difficult for the West to take such steps.

We took our preparations for the meeting with the G7 leaders very seriously. In July, the working group preparing papers and proposals for the London meeting worked practically day and night, and on July 8 it presented the results of its work to the leaders of the republics in NovoOgarevo. The discussion that followed produced a common position based on mutual understanding between the Soviet president and the republics' leaders. All of them, starting with Boris Yeltsin, supported the papers prepared at Novo-Ogarevo and the draft of my presentation to the G7 leaders in London.

Here is the central idea of my speech: "Our concept of integrating our country into the global economy implies the need for radical changes in the USSR as well as reciprocal steps by the West, such as lifting legislative and other restrictions on economic and technical ties with the USSR, the participation of the USSR in international economic organizations, and so on."

The discussion with the Western leaders turned out to be frank and serious. Most of them, however, did not show a real understanding of how much was at stake. Given the significance and the scale of the efforts to integrate the country into the global economy and of the assistance needed for that, the agreements reached in London did not go far enough. As Margaret Thatcher, who had stepped down as UK prime minister a few months earlier, told me when we met in the Soviet Embassy, they did not measure up.

Some commentators later suggested that had the agreements on economic support for perestroika been more concrete and binding, the August coup plotters would probably not have dared attempt a putsch against me. 
Overall, however, my assessment of what happened at my meeting with the G7 remains positive. The London summit marked a major turn: following the changes in the political and military sphere, it was the beginning of the work to dismantle the barriers that had hindered our integration into the global economy.

In late July, U.S. President George Bush came to the USSR on an official visit. Looking back, I think that if the president had moved resolutely to work with us from the very start, the results that this visit produced could have been achieved even earlier. This does not, however, diminish their importance. We signed a treaty to reduce strategic offensive forces by 50 percent. Never before-nor since-have such massive cuts been made to nuclear arsenals. This alone makes the 1991 U.S.-Soviet summit a historic event.

Our private discussions on the key problems of world affairs and the prospects of U.S.-Soviet relations contained very new content.

For me, the main theme of those talks was the prospect of shaping a new system of comprehensive security, which for the first time in history would be the product of a common approach to world affairs, based on new criteria that had already undergone a kind of stress test.

Today, I recall that visit of the U.S. president, his last to the Soviet Union, with some sadness. We did not know then what would happen just three weeks later.

\section{THERE WOULD HAVE BEEN SOMEONE ELSE}

Two blows proved fatal to perestroika: the attempted coup organized by the reactionary forces, including elements close to me, in August 1991 and the collusion of the leaders of Russia, Ukraine, and Byelorussia in December, which cut off the age-old history of our state.

The coup plotters had lost in an open political struggle; they knew that there would be no place for them in a renewed Union. Their assertions that their motives were patriotic and that they acted to preserve the Union are demagogical. It is not that they were indifferent to the fate of our state, but they identified it with the old system and committed betrayal in an attempt to preserve it as well as their place in it. The consequences for the country were catastrophic. 
There is no need here to recount in detail the events of August 1991. I never changed my position and I am responsible for every word I said publicly, in the testimonial evidence I gave to investigators, and in my interviews and books. It is the coup plotters and their defenders who keep changing their "versions of events," and in each of those versions, there are more and more lies.

Those three days in August were an almost inhuman ordeal for me and my family, but I maintained my presence of mind and I acted. I rejected the ultimatum from the conspirators, who demanded that I declare a state of emergency, and I videotaped a statement denouncing their actions as illegal. This, and the firm stand taken by President of Russia Boris Yeltsin, who stated that the coup was unconstitutional, condemned the coup to defeat.

Nevertheless, the coup attempt weakened the position of the president of the USSR, frustrated the process of building new Union relationships between the sovereign states and gave an impetus to disintegration. The republics, one after another, adopted declarations of independence. Still, I believed that even in such circumstances I must not give up. While I fully understood how much more difficult my task had become, I continued to fight for a Union treaty to be concluded. The leaders of the republics and I succeeded in drafting and signing a joint statement that we presented to the Congress of People's Deputies. It proposed that all republics that so wished should elaborate and sign a treaty on the Union of Sovereign States in which every republic would be able independently to decide the form of its participation.

There was a chance to prevent disintegration. After difficult, sometimes arduous discussions, we arrived at the formula for a new Union: a confederative Union State. In mid-October, eight republics signed a treaty of economic community, and the inter-republican economic committee began to function. On November 14, a draft new Union Treaty was submitted to the State Council. After many hours of debate, we went out to face the media. Boris Yeltsin then said:

"It is hard to say how many republics will join, but I am firmly convinced that there will be a Union."

The participation of Ukraine was a difficult issue. Following the coup attempt, the mood in Ukrainian society had turned 
towards independence. Yet I was convinced that gradually, through negotiations, we would be able to find a format in which that state, too, would be willing to participate in a new Union; we could at least agree on common armed forces and coordinated foreign policy. I am sure that much of what happened later, bringing so much grief to so many people, could have been avoided had we succeeded.

Yeltsin did not keep his word. He and his inner circle sacrificed the Union to their wanton desire to reign in the Kremlin.

The leaders of Russia, Ukraine, and Byelorussia decided the fate of the Union in an unlawful way and against the will of the people as expressed in the March 17 referendum. They were guided, above all else, by their intent "to remove Gorbachev." This brought together the radical, separatist and Communist members of Russia's Supreme Soviet, who voted as one to approve the outcome of the collusion sealed on December 8, 1991, at Belovezhskaya Pushcha. They did not think about the consequences. Even the problem of the armed forces and nuclear weapons was left in limbo: the common armed forces quickly disintegrated, while the statement of intent "to preserve under unified command the common military-strategic space, including single control of nuclear weapons" turned out to be empty rhetoric. Even the Americans were amazed by how hastily and irresponsibly the Belovezhskaya Pushcha agreements had been made.

What amazed and, more than that, shocked me was the indifference of public opinion, which did not condemn the disintegration of the Union. People failed to understand that they were losing their country...

I am still asked: Are you sure that after the Belovezhskaya Pushcha collusion you did everything possible and used all the powers of the presidency to preserve the Union?

My answer is yes, I used all the political powers and all means other than the use of force. The person who would have used force to hang on to power would have been someone other than Gorbachev.

And what could it have led to? It could have divided all institutions, including the army and the police, leading to civil strife and possibly even civil war. To me, that was out of the question. 


\section{THE VALUES OF PERESTROIKA}

The collapse of the Soviet Union stopped perestroika, but in no case was it its "upshot," as my opponents and people who did not understand the essence of that era still claim. And in general, perestroika should not be assessed by what it was able to give or failed to give, but by the magnitude of changes it brought about in the centuries-old history of Russia, by its positive effects on the whole world.

I am often asked about how I assess certain decisions of those years, what was right and what was wrong.

We made mistakes, of course. Some of them were mentioned above. We should have started earlier to reorganize the Party, decentralize the Union, and overhaul the economy more vigorously.

But here are the real results of perestroika: the end of the Cold War, unprecedented agreements on nuclear disarmament, the acquisition by people of rights and freedoms - the freedom of speech, assembly, and religion, the freedom to leave the country, competitive elections, a multi-party system. And most importantly, we brought the process of change to the point where it became impossible to reverse it.

But the road Russia and other republics traveled after the disruption of perestroika turned out to be hard and bumpy. The breakdown of ties, ill-advised economic decisions, immaturity and the absence of genuine democratism among the rulers who came to power led to dramatic and sometimes tragic consequences. It was easy to criticize perestroika, lay all the blame on its initiators, and destroy; creating something new on the ruins they caused themselves was much more difficult.

I warned about the consequences of radicalism and irresponsibility that reigned in Russia in the 1990s. And those warnings proved correct: damage was caused not only to the economy, but also to democratic institutions.

We are still far from the goals that were set at the very start of our transformations-alternation of power and creation of reliable mechanisms that would allow people to influence the decision-making process. But still, we did not roll back or mark time in the past decades. All these years, when assessing events, sometimes critically, and often positively, I called for preserving the ideals and values of perestroika. These are the landmarks without which we can lose our way 